\title{
THE EFFECT OF THE MODEL OF ERADICATION OF DENGUE FEVER VECTOR MOVEMENT OF HOUSEWIVES MONITORING LARVA IN EFFORTS TO PREVENT DENGUE FEVER IN MOJOLANGU VILLAGE, LOWOKWARU DISTRICT MALANG
}

\author{
Fiashriel Lundy, Prima Soultoni Akbar \\ School of Health Polytechnics, Ministry of Health Malang
}

\begin{abstract}
Background: In recent years, the incidence and geographic distribution of dengue fever have greatly increased. Dengue fever is an acute viral disease transmitted by mosquitoes and is characterized by fever, headache, muscle and joint pain, skin rash, nausea and vomiting. The Mosquito Nest Eradication Program (PSN) through 3M Plus needs to be carried out continuously throughout the year, especially in the rainy season through the movement of housewife who monitor larvae. This study aimed to determine the effect of the dengue fever vector eradication model through the housewife movement of larva monitoring in the efforts of dengue fever prevention in Mojolangu Village, Malang City.

Subjects and Method: This was a quasi-experiment using 2 treatment groups and 1 control group conducted at Mojolangu village, Lowokwaru district, Malang. A sample of 90 respondents divided into three groups was selected by purposive sampling. The dependent variable was DHF Prevention Efforts (Larva Monitoring). The independent variables were Dengue Fever Vector Eradication Model. The data were collected by questionnaire and observation. The data was analyzed by Kruskal-Wallis.

Results: After being given treatment in group 1 (educated by health workers) and group 2 (trained cadres) the ability increased to be very good by $83 \%$ and $53 \%$. In group 3 (control) his ability improved by $37 \%$. Group 1 has the most effective influence in increasing knowledge and skills. Then group 2 with a significance value of $<0.001(\mathrm{p}<0.005)$.

Conclusion: Housewife are a resource in Family Empowerment and Intervention models. The eradication of dengue vectors needs regular monitoring and monitoring so that self-awareness and independence from the family can increase so that the degree of health can be achieved optimally.
\end{abstract}

Keywords: Model, eradication, vector, dengue fever, larva

\section{Correspondence:}

Fiashriel Lundy. School of Health Polytechnics, Ministry of Health Malang. Jl. Besar Ijen No 77, Oro-oro Dowo, Klojen sub-distric, Malang, East Java. Email: fiashriellundy@yahoo.com. Mobile: 0811367446 